\title{
Genetic diversity and mycelial compatibility groups of the plant-pathogenic fungus Sclerotinia sclerotiorum in Brazil
}

C.G. Litholdo Júnior ${ }^{1}$, E.V. Gomes ${ }^{1}$, M. Lobo Júnior ${ }^{2}$, L.C.B. Nasser ${ }^{3}$ and S. Petrofeza ${ }^{1}$

${ }^{1}$ Instituto de Ciências Biológicas, Universidade Federal de Goiás, Goiânia, GO, Brasil

${ }^{2}$ Embrapa Arroz e Feijão, Santo Antônio de Goiás, GO, Brasil

${ }^{3}$ EMBRAPA - Centro de Pesquisa Agropecuária dos Cerrados,

Planaltina, DF, Brasil

Corresponding author: S. Petrofeza

E-mail: petrofeza@icb.ufg.br

Genet. Mol. Res. 10 (2): 868-877 (2011)

Received May 31, 2010

Accepted September 20, 2010

Published May 17, 2011

DOI 10.4238/vol10-2gmr937

\begin{abstract}
The genetic variability of 40 Sclerotinia sclerotiorum isolates from various fields widely distributed throughout Brazil and different host crops was analyzed using RAPD markers and mycelial compatibility groupings (MCGs). The isolates were characterized using 16 random primers of the OPERON series, which produced 121 DNA fragments. UPGMA cluster analysis using Jaccard's genetic distance and MCGs allowed separation of the isolates into three clusters, with similarity indices of 68.2, 61.8, and 61.8\%, and five MCGs. The haplotypes obtained with RAPD markers provided very characteristic groupings of $S$. sclerotiorum isolates according to MCG, but did not show any relationship with geographic origin or host type. Furthermore, analysis of molecular variance demonstrated that $99.1 \%$ of the observed variation was a result of genetic differences between individuals; the host culture did not have a significant effect. This is the first report of high level variability of $S$. sclerotiorum in Brazil based on the study of isolates of wide geographical
\end{abstract}


origin, supported by RAPD markers and MCGs. These results endorse the prevalence of sexual reproduction in tropical and subtropical regions in contrast to clonal reproduction in temperate regions.

Key words: Sclerotinia sclerotiorum; White mold; Genetic diversity; RAPD; Mycelial compatibility groups

\section{INTRODUCTION}

Sclerotinia sclerotiorum (Lib.) de Bary is one of the most devastating and cosmopolitan soilborne plant pathogens and infects over 400 species of plants worldwide. The majority of these species are dicotyledonous, although a number of agriculturally significant monocotyledonous plants are also S. sclerotiorum hosts (Boland and Hall, 1994). Annual yield losses due to Sclerotinia diseases exceed millions of dollars each year all over the world. Extensive crop damage, lack of high levels of host resistance, and the general difficulty of managing diseases caused by Sclerotinia have been the impetus for sustainable research on this pathogen.

Studies on the population structure and diversity of S. sclerotiorum have demonstrated the occurrence of genotype diversity and have provided evidence for both clonal and sexual reproduction. In general, clonal reproduction has been shown to be predominant in temperate climate regions, whereas sexual recombination contributes to population structure in milder climates (Cubeta et al., 1997; Kohli and Kohn, 1998; Carpenter et al., 1999; Atallah et al., 2004; Sun et al., 2005; Malvárez et al., 2007; Arbaoui et al., 2008). Individual isolates are classified into clonal lineages by the use of two or more independent markers, such as mycelial compatibility groups (MCGs), DNA fingerprinting, or microsatellites (Kohn et al., 1991; Carbone et al., 1999; Sirjusingh and Kohn, 2001; Hambleton et al., 2002; Auclair et al., 2004).

MCG testing is a phenotypic, macroscopic assay of the self/non-self recognition system controlled by multiple loci, which is common in fungi (Carbone et al., 1999). Mycelial incompatibility is the failure of different strains to fuse and form one cohesive colony and is characterized by the formation of dead cells and reduced growth between the two incompatible colonies (Kohn et al., 1991).

Mycelial compatibility can be viewed as an indirect measure of genetic diversity in populations, as it does not reveal the degree of relatedness between or within MCGs. However, a number of molecular techniques are available for the investigation of genetic variability both within and between MCGs. These include random amplified polymorphic DNA (RAPD) analysis (Williams et al., 1990), a technique that has been proven useful at the species and subspecies levels of other fungal genera. In S. sclerotiorum, RAPD markers were very effective for identifying genetic differences between isolates from different regions and host plants in China (Sun et al., 2005).

Previous population genetics studies on S. sclerotiorum have demonstrated an association between MCGs, DNA fingerprints, and microsatellite markers (Carpenter et al., 1999; Hambleton et al., 2002; Sexton and Howlett, 2004; Sexton et al., 2006), although Atallah et al. (2004) reported no association between MCGs and microsatellite markers in potato isolates.

In Brazil, white mold occurs primarily in many economically important crops, such as common bean, soybean, cotton and several vegetables, among others, and can cause serious yield losses. This pathogen was first reported in the country in the 1920s and spread to the main agricultural regions probably due to infected seeds. Despite the presence of S. sclero- 
tiorum for decades in Brazil and extensive literature about its agronomic aspects, information about the population biology of this pathogen in this country is still emerging.

Therefore, the objectives of this study were: a) to determine the genetic variation of an S. sclerotiorum population using MCGs and RAPD analyses of isolates collected in representative agricultural areas in the Brazilian States of Goiás, Minas Gerais, São Paulo, Espírito Santo, and Paraná, and in the Distrito Federal, as well as from host plants; b) to determine whether the same genotypes of S. sclerotiorum were found associated with different crops, and c) to determine whether the relatively strict association between MCGs and RAPD haplotype or MCGs and host occurred in the populations or regions under study.

\section{MATERIAL AND METHODS}

\section{Fungal isolates}

Forty isolates used in this investigation were collected from representative crop production regions in the Brazilian States of Goiás, Minas Gerais, São Paulo, Espírito Santo, and Paraná, and in the Distrito Federal, from different hosts and under varied agro-climatic conditions (Figure 1). The isolates were stored in a collection maintained at the Universidade Federal de Goiás. Sclerotia were removed from plant tissue or culture, immersed in a mixture of $4 \%$ sodium hypochlorite and $70 \%$ ethanol for $2 \mathrm{~min}$, rinsed in sterile distilled water, blotted dry on sterile filter paper, plated on potato dextrose agar (PDA) medium, and grown in the dark at room temperature for 3 days.

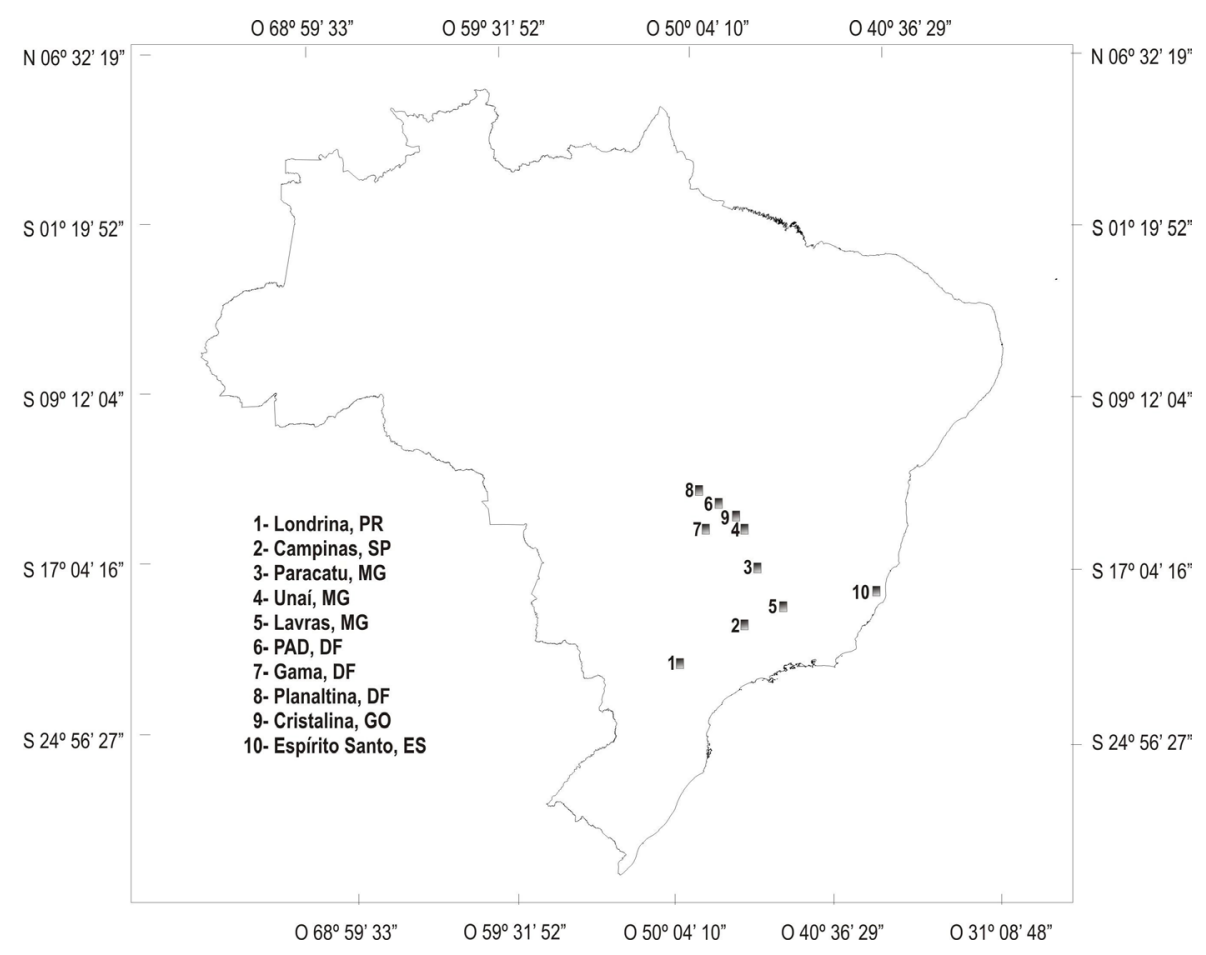

Figure 1. Map of Brazil and origin of the Sclerotinia sclerotiorum isolates used in this study. 


\section{DNA manipulation}

Single sclerotium isolates were incubated at $28^{\circ} \mathrm{C}$ for 3 days on Petri dishes containing solid PDA medium. Single 3-mm mycelial plugs excised from the margin of the colonies grown on PDA were introduced into conical flasks containing $50 \mathrm{~mL}$ potato dextrose broth and maintained at $28^{\circ} \mathrm{C}$ in a shaker at $120 \mathrm{rpm}$ for 10 days. Mycelium was collected by filtration, washed with saline, and kept in liquid nitrogen until use. DNA extraction was performed according to the protocol described by Zolan and Pukkila (1986). DNA quantification was determined by spectrophotometry and visualization under ultraviolet light after electrophoresis on $0.8 \%$ agarose gels prepared with $1 \mathrm{X}$ TBE (Tris-borate-EDTA) and staining with ethidium bromide $(0.5 \mu \mathrm{g} / \mathrm{mL}$ in water) (Sambrook et al., 1989).

\section{Random amplified polymorphic DNA}

Primers OPC02, OPC06, and OPE03 to 20 (Operon Technologies, Inc., Alameda, CA, USA) were used for RAPD analyses. Each amplification reaction was carried out in a $30-\mu \mathrm{L}$ solution [10 ng template genomic DNA, $0.2 \mathrm{mM}$ of each of four dNTPs, $2.5 \mathrm{U}$ Taq DNA polymerase (Invitrogen), $1.5 \mathrm{mM} \mathrm{MgCl} 2,1 \mathrm{X}$ buffer (Invitrogen)]. Amplifications were performed with a PTC 100 MJ DNA thermocycler with the following temperature profiles: 1 cycle at $95^{\circ} \mathrm{C}$ for $5 \mathrm{~min} ; 35$ cycles at $94^{\circ} \mathrm{C}$ for $1 \mathrm{~min}, 45^{\circ} \mathrm{C}$ for $1 \mathrm{~min}$ and $72^{\circ} \mathrm{C}$ for $2 \mathrm{~min}$, and $1 \mathrm{cycle}$ at $72^{\circ} \mathrm{C}$ for $5 \mathrm{~min}$. To ensure reproducibility, all polymerase chain reactions (PCRs) were performed in duplicate for each isolate. RAPD-PCR products were separated by electrophoresis on $1.5 \%$ agarose gels, using $1 \mathrm{X}$ TBE buffer ( 2 mM EDTA; $0.1 \mathrm{M}$ Tris-HCl; $0.1 \mathrm{M}$ boric acid, $\mathrm{pH} 8.0$ ), at a constant voltage of $4 \mathrm{~V} / \mathrm{cm}$. DNA fragments were visualized by UV examination employing ethidium bromide $(0.5 \mu \mathrm{g} / \mathrm{mL}$ in water) staining, and photographed using the Eagle Eye II photodocumentation system (Stratagene, New Jersey, USA). EcoRI/HindIII digested $\lambda$ phage DNA was included as a size marker in all gels to estimate DNA band sizes.

To record RAPD patterns, a binary data matrix was prepared for each isolate and primer, in which intense DNA fragments (RAPD bands) were scored as 1 when present or 0 when absent. DNA fragments of the same size, produced from $S$. sclerotiorum isolates by a single primer, were considered to be identical. Each isolate was identified regarding the presence (1) or absence (0) of the fragment amplified, resulting in a matrix. The SM, DICE and Jaccard's similarity coefficients were used to construct a pairwise similarity matrix, which was employed to perform hierarchical cluster analyses based on the unweighted pair group method with arithmetic mean (UPGMA) using the NTSYS software, version 1.80 (Rohlf, 1993). To determine the statistical significance of the dendrogram branches, the data were bootstrapped with 1000 replications using the WinBoot program (Yap and Nelson, 1996). The genetic differentiation within and between populations/hosts was estimated by analysis of molecular variance (AMOVA) using the Arlequin v. 3.0 program (Excoffier et al., 2005).

\section{Mycelial compatibility groups}

Fungal cultures of the 40 isolates of S. sclerotiorum were paired in all possible combinations on PDA to identify compatible strains. Mycelial compatibility was determined using the method described by Kohn et al. (1990). Isolates were paired by placing an agar plug (3 
$\mathrm{mm}$ in diameter) of each onto PDA medium containing $30 \mathrm{drops} / \mathrm{L}$ red food coloring. Pairs of isolates were assessed after 6 days. Compatible reactions were recorded when two colonies merged without forming a dark line or a strip of thin mycelium and when sclerotial formation was continuous. Incompatible reactions were recorded when a reaction line was formed between the two colonies. Multiple isolates from each group were tested against isolates from all the other groups.

\section{RESULTS}

\section{Mycelial compatibility testing}

Mycelial pairings of the strains in all combinations on agar medium produced either an incompatible reaction in which a reaction line between the two strains developed in the interaction zone, or a compatible reaction in which no reaction line developed (Figure 2). Among the 40 strains obtained from different regions, five MCGs were recognized - A, B, C, $\mathrm{D}$, and $\mathrm{E}$ (Table 1). We observed that MCG-A was the most prevalent group in all regions, accounting for $40 \%$ of the total isolates; MCG-B and MCG-C accounted for 30 and $17.5 \%$ of the total isolates, respectively, distributed all over the surveyed areas; MCG-D accounted for $7.5 \%$ of the total isolates and was limited to the Distrito Federal, and MCG-E accounted for $5.0 \%$ of the total isolates and occurred only in Londrina, in the State of Paraná, with two isolates obtained from sunflower (Helianthus annuus L.) (Table 1).

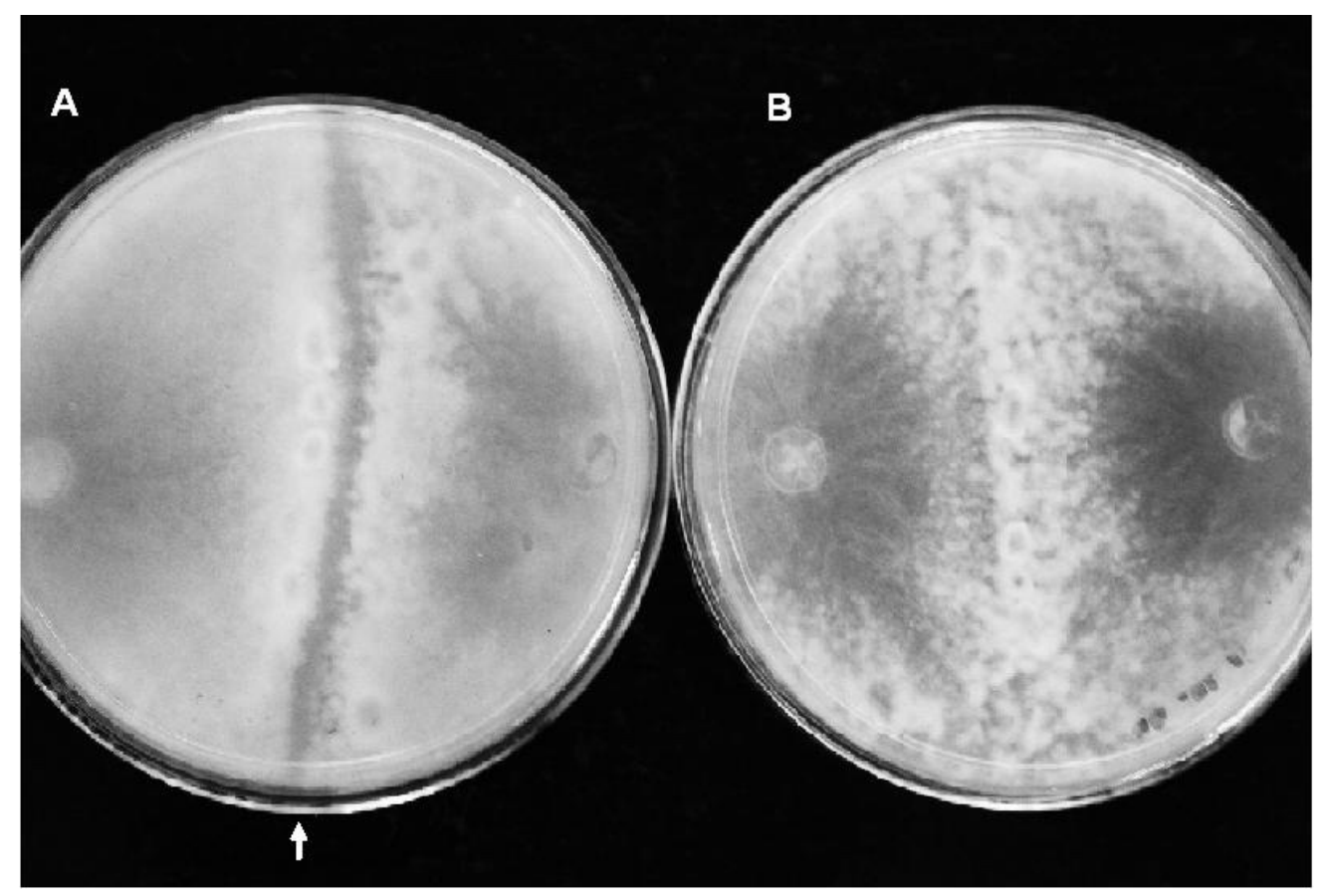

Figure 2. Representative results from each mycelial compatibility group (MCG) testing. A. Incompatible reaction. B. Compatible reaction. MCGs were determined using the method described by Kohn et al. (1990). 


\begin{tabular}{|c|c|c|c|c|}
\hline Isolate number & Host origin & Location $^{1}$ & $\mathrm{MCG}^{2}$ & RAPD haplotype ${ }^{3}$ \\
\hline 1 & Common bean (Phaseolus vulgaris L. cv. Pérola) & Unaí, MG & A & $\mathrm{I}$ \\
\hline 2 & Common bean (P. vulgaris L. cv. Pérola) & Unaí, MG & $\mathrm{B}$ & I \\
\hline 3 & Common bean (P. vulgaris L. cv. Pérola) & Unaí, MG & A & I \\
\hline 4 & Common bean (P. vulgaris L. cv. Pérola) & Unaí, MG & A & I \\
\hline 5 & Common bean (P. vulgaris L. cv. Pérola) & Unaí, MG & A & I \\
\hline 6 & Common bean (P. vulgaris L. cv. Pérola) & Unaí, MG & A & $\mathrm{I}$ \\
\hline 7 & Common bean (P. vulgaris L. cv. Pérola) & Paracatu, MG & $\mathrm{B}$ & I \\
\hline 8 & Common bean (P. vulgaris L. cv. Pérola) & Cristalina, GO & $\mathrm{B}$ & I \\
\hline 9 & Common bean (P. vulgaris L. cv.Pérola) & Cristalina, GO & $\mathrm{B}$ & I \\
\hline 10 & Common bean (P. vulgaris L. cv. Carioca) & Paracatu, GO & $\mathrm{C}$ & I \\
\hline 11 & Common bean (P. vulgaris L. cv. Carioca) & Paracatu, GO & $\mathrm{C}$ & I \\
\hline 12 & Common bean (P. vulgaris L. cv. Carioca) & Paracatu, GO & $\mathrm{B}$ & I \\
\hline 13 & Tomato (Lycopersicon esculentum) & Cristalina, GO & $\mathrm{C}$ & III \\
\hline 14 & Tomato (L. esculentum) & Cristalina, GO & $\mathrm{B}$ & I \\
\hline 15 & Tomato (L. esculentum) & Cristalina, GO & A & I \\
\hline 16 & Tomato (L. esculentum) & Cristalina, GO & $\mathrm{B}$ & I \\
\hline 17 & Tomato (L. esculentum) & Cristalina, GO & $\mathrm{B}$ & I \\
\hline 18 & Tomato (L. esculentum) & Cristalina, GO & $\mathrm{C}$ & III \\
\hline 19 & Tomato (L. esculentum) & Gama, DF & A & I \\
\hline 20 & Tomato (L. esculentum) & PAD-DF, DF & $\mathrm{A}$ & I \\
\hline 21 & Pepper (Capsicum annuит L.) & Espírito Santo, ES & A & I \\
\hline 22 & Pepper (C. annuиm L.) & Lavras, MG & A & I \\
\hline 23 & Pepper (C. annuum L.) & Lavras, MG & $\mathrm{A}$ & I \\
\hline 24 & Pepper (C. annuum L.) & Lavras, MG & $\mathrm{C}$ & III \\
\hline 25 & Pepper (C. annuит L.) & Lavras, MG & $\mathrm{C}$ & III \\
\hline 26 & Lentil (Pisum sativum L.) & Gama, DF & $\mathrm{B}$ & I \\
\hline 27 & Lentil (P. sativum L.) & Gama, DF & A & I \\
\hline 28 & Lentil (P. sativum L.) & Gama, DF & $\mathrm{B}$ & I \\
\hline 29 & Lettuce (Lactuca sativa L.) & Campinas, SP & $\mathrm{B}$ & I \\
\hline 30 & Lettuce (L. sativa $\mathrm{L})$. & PAD-DF, DF & $\mathrm{C}$ & I \\
\hline 31 & Sunflower (Helianthus annuus L.) & Londrina, PR & $\mathrm{E}$ & I \\
\hline 32 & Sunflower (H. annuus L.) & Londrina, PR & $\mathrm{E}$ & I \\
\hline 33 & Sunflower (H. annuus L.) & Londrina, PR & A & II \\
\hline 34 & Carrot (Daucus carota L.) & PAD-DF, DF & A & I \\
\hline 35 & Carrot (D. carota L.) & PAD-DF, DF & $\mathrm{D}$ & II \\
\hline 36 & Radish (Raphanus sativus L.) & Planaltina, DF & $\mathrm{D}$ & II \\
\hline 37 & Radish (Raphanus sativus L.) & Planaltina, DF & $\mathrm{D}$ & II \\
\hline 38 & Lentil (Pisum sativum L.) & Gama, DF & $\mathrm{A}$ & I \\
\hline 39 & Canola (Brassica napus L.) & Londrina, PR & $\mathrm{B}$ & I \\
\hline 40 & Cabbage (Brassica oleraceae L.) & PAD-DF, DF & A & I \\
\hline
\end{tabular}

${ }^{1}$ States of Goiás (GO), Minas Gerais (MG), São Paulo (SP), Espírito Santo (ES), and Paraná (PR), and the Distrito Federal (DF). ${ }^{2}$ MCGs were determined using the method described by Kohn et al. (1990). ${ }^{3}$ RAPD haplotype used Jaccard's coefficient (see Figure 3).

\section{RAPD-PCR analysis}

S. sclerotiorum isolates evaluated in the present study were characterized using 16 random primers of the OPC and OPE series and produced a total of 121 DNA fragments of which $65 \%$ were polymorphic, ranging in size from 0.46 to $2.16 \mathrm{~kb}$.

The three dendrograms generated using the SM, DICE, and Jaccard's coefficients showed the same structure and the same clusters. The dendrograms generated (Jaccard's coefficient) have three distinct clusters at $60.6 \%$ of distance (Figure 3). Cluster I, with the highest degree of genetic variation, comprises 32 isolates from different regions and hosts; cluster II has four isolates, from sunflower, radish (Raphanus sativus L.), and carrot (Daucus carota L.) collected in distinct geographical locations, and cluster III contains four isolates, from tomato 
(Lycopersicum esculentum L.) and pepper (Capsicum annuum L.). The robustness of the tree was estimated by bootstrap resampling, and the bootstrap values for clusters I, II, and III were very high, 100, 98 , and $100 \%$, respectively.

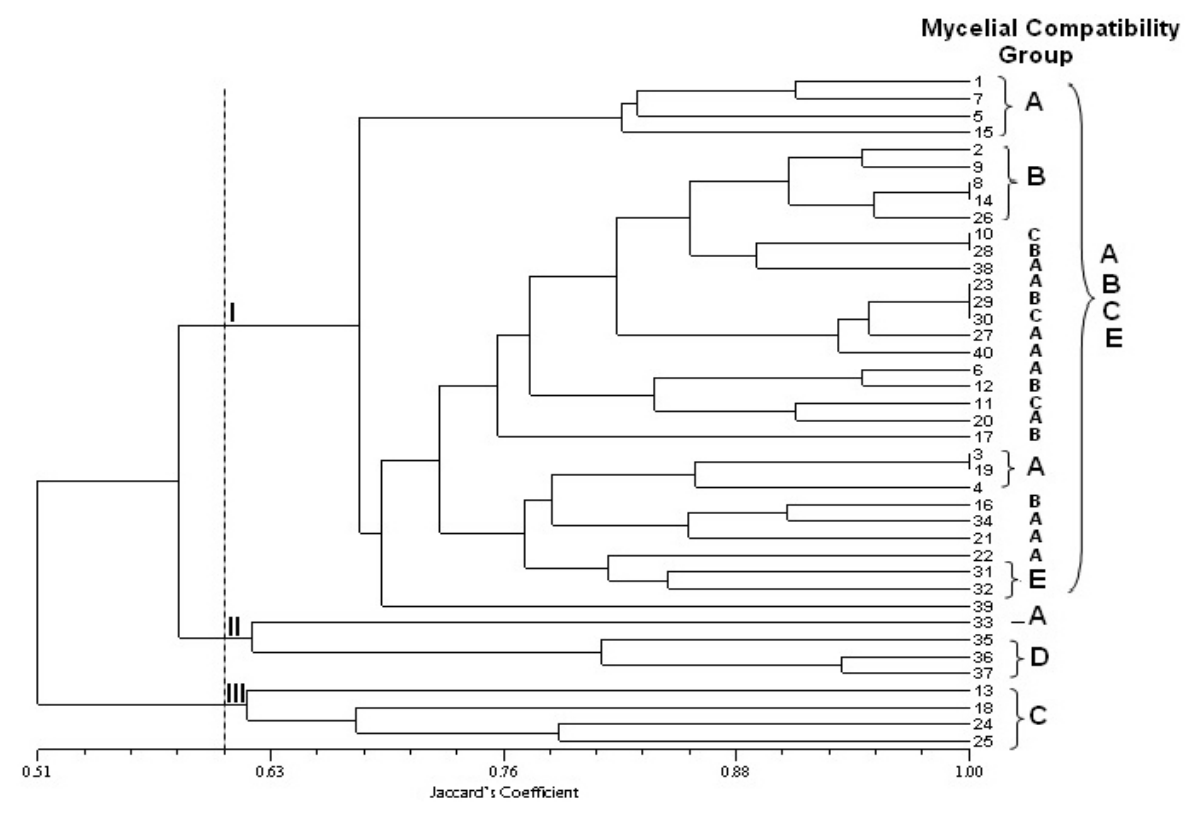

Figure 3. Unweighted pair group method with arithmetic mean (UPGMA) dendrograms showing the genetic relationships between the 40 isolates of Sclerotinia sclerotiorum assessed in this study, based on random amplified polymorphic DNA (RAPD) markers (Jaccard's coefficient) and their respective mycelial compatibility groups.

The results of AMOVA indicated that $99 \%$ of the total molecular variance was due to differences between isolates within geographic regions and only $0.89 \%$ of the variance was associated with differences between hosts (Table 2).

\begin{tabular}{|c|c|c|c|c|c|c|}
\hline $\begin{array}{l}\text { Molecular marker/variance } \\
\text { component }\end{array}$ & d.f. & Sum of squares & Variance & Variation (\%) & F-statistics (Фst) & $\mathrm{P}$ \\
\hline Among hosts & 9 & 104.02 & 0.19 & $0.89 \%$ & 0.0089 & 0.3069 \\
\hline Among individuals/within hosts & 30 & 1657.05 & 22.08 & $99.1 \%$ & & 0.0000 \\
\hline Total & 39 & 1761.07 & 22.27 & & & \\
\hline
\end{tabular}

d.f. $=$ degrees of freedom. $\Phi$ st values significant for $\mathrm{P}=0.01$.

Comparing RAPD clustering and MCG profiles, we observed a strong association between MCGs and the genetic distance for isolates derived from the different areas examined (Figure 3). Although the different isolates of cluster I exhibited nearly $68 \%$ similarity, it grouped isolates from different MCGs (A, B, C, and E). However, a subcluster contained four isolates (1, 7, 5, and 15), which, despite their distinct geographical origins, were grouped in MCG-A. These isolates were clearly different from those from the other clusters. Similarly, another subcluster was also observed 
in MCG-E isolates (31 and 32). Cluster II showed isolates predominantly classified as MCG-D, whereas cluster III consisted of MCG-C isolates. These data indicate a trend toward an association between MCG and genetic distance of the isolates regardless of their geographical origin or host.

There were several cases in which one MCG was associated with more than one RAPD haplotype and two cases [(isolates 10 MCG-C and 28 MCG-D) and (isolates 23 MCG-A, 29 MCG$\mathrm{B}$, and $30 \mathrm{MCG}-\mathrm{C})$ ] in which one RAPD haplotype was associated with more than one MCG.

In our study, there was no apparent clustering according to host or geographic area for MCGs. Nevertheless, MCGs containing isolates from more than one host and geographic area (groups C, D, and E) clustered separately from groups containing isolates from only one host or geographic area (MCG-A) (Figure 3). Therefore, it seems that groups with a narrow host range are genetically dissimilar to those with a wider host range.

\section{DISCUSSION}

This study is the first to compare the genetic diversity of $S$. sclerotiorum in crop production systems in different geographical locations of Brazil. To determine whether S. sclerotiorum isolates collected in different regions were predominantly clonal or occurred through genetic exchange and recombination, 40 S. sclerotiorum isolates representing different hosts and agroclimatic conditions in six regions of Brazil were examined. The results obtained using MCG and RAPD markers revealed a high level of variability among these isolates, suggesting the occurrence of sexual recombination in the population in addition to clonal reproduction.

Previous reports on S. sclerotiorum have revealed a predominantly clonal mode of reproduction (Kohli et al., 1995; Cubeta et al., 1997; Kohli and Kohn, 1998) and that genetic exchange and recombination occurs occasionally in populations of this pathogen obtained from canola (Kohli and Kohn, 1998; Sexton and Howlett, 2004; Sexton et al., 2006; Mert-Türk et al., 2007), cabbage (Cubeta et al., 1997), and soybean (Kull et al., 2004), with different MCGs identified. However, populations of S. sclerotiorum collected from infected potato not only exhibited high diversity, but also demonstrated the potential for sexual recombination, with different MCGs identified from ascospores obtained from one apothecium (Atallah et al., 2004).

In Brazil, few studies have demonstrated genetic variability in populations of S. sclerotiorum. Using 21 isolates of $S$. sclerotiorum from common bean and two from other crops (potato and bell pepper) collected in different regions of Brazil, Meinhardt et al. (2002) showed the presence of only two MCGs. DNA amplification with a chromosomal telomere sequence-based primer and one microsatellite primer revealed genetic polymorphisms among isolates within the same MCG.

The structure and dynamics of the populations of S. sclerotiorum represent an essential part of understanding how the underlying mechanisms are involved in pathogen history and distribution along different geographic areas and hosts. Phillips et al. (2002) identified an association between rDNA intergenic spacer haplotypes and symptom type in canola in southeastern USA. The authors hypothesized that some S. sclerotiorum genotypes may be adapted to many hosts, while others may have become more specific to canola.

In the present study, RAPD marker analysis resulted in the formation of three clusters with similarity indices of $68.2,61.8$, and $61.8 \%$. The distribution of the isolates indicated no tendency toward the formation of clusters with respect to geographical origin or host, showing that both hypotheses of occurrence of specific populations for each crop or genotype distribution restricted to a region were disregarded. This was confirmed by AMOVA, which showed 
evidence of a statistically significant population structuring, with minimal impact on the total variability of the crop population or region of collection. Sun et al. (2005) compared three $S$. sclerotiorum populations collected from different sites across Europe, China, and Canada and found that the genetic differentiation between and within populations was highly significant.

A comparison of the isolates under study by RAPD-PCR amplifications showed no clear relationship between the host and MCG, except that many isolates from the same host belonged to the same MCG. As already mentioned, we observed that in several cases one MCG was associated with more than one RAPD haplotype, and also, that one RAPD haplotype was associated with more than one MCG, suggesting the occurrence of recombination.

Although isolates from the same MCG differed from one another, such as isolates from groups $\mathrm{D}$ and $\mathrm{E}$, they tended to cluster closer together, suggesting a smaller degree of genetic variability within a group and a larger degree of variability between groups.

In several studies conducted in other countries, using the multicopy element for DNA fingerprinting, the authors also found a close association between mycelial compatibility group and haplotype (Kohli and Kohn, 1998; Carpenter et al., 1999; Hambleton et al., 2002; Sexton and Howlett, 2004).

In other studies, the authors found that MCGs or microsatellite markers were not associated with specific virulence characteristics or ecological adaptations of the pathogen (Atallah et al., 2004; Auclair et al., 2004; Kull et al., 2004; Sexton and Howlett, 2004), which was also observed in our study. Nonetheless, diversity can be a function of a number of factors, both related to agronomic characteristics and inherent to the biology of the pathogen. The occurrence of the most prevalent isolate (MCG-A) in common bean (Phaseolus vulgaris L.) production areas (Cristalina, GO, and Unaí/ Paracatu, MG) could be an indication of seedborne dispersal or an exchange of inocula (sclerotia) between the areas, given that some farm equipment/tools are shared and moved around within these areas. Similarly, in the other areas where most isolates belonged to a single MCG (D and E), it is possible that the effects of propagule movement were limited. However, to confirm this hypothesis, further investigations are required using a larger number of isolates from each area and region.

This is the first report of a high-level variability in S. sclerotiorum in Brazil, supported by RAPD markers and MCGs. These results with isolates of different geographical origin, endorse the prevalence of sexual reproduction in tropical and subtropical regions in contrast to clonal reproduction in temperate regions. The association between mycelial compatibility populations and the probable occurrence of sexual recombination indicates the potential for the emergence of different genotypes in each area and highlights the need to maintain agricultural practices that restrict gene flow between populations around the country. Moreover, further research is needed to investigate the extent and mechanisms of genetic variation and dispersal in different regions of Brazil.

\section{ACKNOWLEDGMENTS}

Research supported by Conselho Nacional de Desenvolvimento Científico e Tecnológico (CNPq) and Fundação de Amparo à Pesquisa do Estado de Goiás (FAPEG).

\section{REFERENCES}

Arbaoui M, Kraic J and Huszár J (2008). Genetic variation of Sclerotinia sclerotiorum isolates from different conditions. Agriculture (Pol'nohospodárstvo) 54: 36-39.

Atallah ZK, Larget B, Chen X and Johnson DA (2004). High genetic diversity, phenotypic uniformity, and evidence of 
outcrossing in Sclerotinia sclerotiorum in the Columbia basin of Washington state. Phytopathology 94: 737-742.

Auclair J, Boland GJ, Kohn LM and Rajcan I (2004). Genetic interactions between Glycine max and Sclerotinia sclerotiorum using a straw inoculation method. Plant Dis. 88: 891-895.

Boland GJ and Hall R (1994). Numbers and distribution of apothecia of Sclerotinia sclerotiorum in relation to white mold of white bean (Phaseolus vulgaris). Can. J. Bot. 66: 247-252.

Carbone I, Anderson JB and Kohn LM (1999). Patterns of descent in clonal lineages and their multilocus fingerprints are resolved with combined gene genealogies. Evolution 53: 11-21.

Carpenter MA, Frampton C and Stewart A (1999). Genetic variation in New Zealand populations of the plant pathogen Sclerotinia sclerotiorum. New Zealand J. Crop Hortic. Sci. 27: 13-21.

Cubeta MA, Cody BR, Kohli Y and Kohn LM (1997). Clonality in Sclerotinia sclerotiorum on infected cabbage in Eastern North Carolina. Phytopathology 87: 1000-1004.

Excoffier L, Laval G and Schneider S (2005). Arlequin (version 3.0): an integrated software package for population genetics data analysis. Evol. Bioinform. Online 1: 47-50.

Hambleton S, Walker C and Kohn LM (2002). Clonal lineages of Sclerotinia sclerotiorum previously known from other crops predominate in 1999-2000 samples from Ontario and Quebec soybean. Can. J. Plant Pathol. 24: 309-315.

Kohli Y and Kohn LM (1998). Random association among alleles in clonal populations of Sclerotinia sclerotiorum. Fungal Genet. Biol. 23: 139-149.

Kohli Y, Brunner LJ, Yoell H, Milgroom MG, et al. (1995). Clonal dispersal and spatial mixing in populations of the plant pathogenic fungus, Sclerotinia sclerotiorum. Mol. Ecol. 4: 69-77.

Kohn LM, Carbone I and Anderson JB (1990). Mycelial interactions in Sclerotinia sclerotiorum. Exp. Mycol. 14: 255-267.

Kohn LM, Stasoviski E, Carbone I, Royer J, et al. (1991). Mycelial incompatibility and molecular markers identify genetic variability in field populations of Sclerotinia sclerotiorum. Phytopathology 81: 480-485.

Kull LS, Pedersen WL, Palmquist D and Hartman GL (2004). Mycelial compatibility grouping and aggressiveness of Sclerotinia sclerotiorum. Plant Dis. 88: 325-332.

Malvárez G, Carbone I, Grunwald NJ, Subbarao KV, et al. (2007). New populations of Sclerotinia sclerotiorum from lettuce in California and peas and lentils in Washington. Phytopathology 97: 470-483.

Meinhardt LW, Wulff NA, Bellato CM and Tsai SM (2002). Telomere and microsatellite primers reveal diversity among Sclerotinia sclerotiorum isolates from Brazil. Fitopatol. Bras. 27: 211-215.

Mert-Türk F, Ipek M, Mermer D and Nicholson P (2007). Microsatellite and morphological markers reveal genetic variation within a population of Sclerotinia sclerotiorum from oilseed rape in the Çanakkale Province of Turkey. $J$. Phytopathol. 155: 182-187.

Phillips DV, Carbone I, Gold SE and Kohn LM (2002). Phylogeography and genotype-symptom associations in early and late season infections of canola by Sclerotinia sclerotiorum. Phytopathology 92: 785-793.

Rohlf FJ (1993). NTSYS-PC: Numerical Taxonomy and Multivariate Analysis System, Version 1.80. State University of New York, Stony Brook, New York.

Sambrook K, Fritsch EF and Maniatis T (1989). Molecular Cloning: a Laboratory Manual. 2nd edn. Cold Spring Harbor Laboratory Press, New York.

Sexton AC and Howlett BJ (2004). Microsatellite markers reveal genetic differentiation among populations of Sclerotinia sclerotiorum from Australian canola fields. Curr. Genet. 46: 357-365.

Sexton AC, Whitten AR and Howlett BJ (2006). Population structure of Sclerotinia sclerotiorum in an Australian canola field at flowering and stem-infection stages of the disease cycle. Genome 49: 1408-1415.

Sirjusingh C and Kohn LM (2001). Characterization of microsatellites in the fungal plant pathogen, Sclerotinia sclerotiorum. Mol. Ecol. Notes 1: 267-269.

Sun JM, Irzykowski W, Jedryczka M and Han FX (2005). Analysis of the genetic structure of Sclerotinia sclerotiorum (Lib.) de Bary populations from different regions and host plants by random amplified polymorphic DNA markers. J. Integr. Plant Biol. 47: 385-395.

Williams JG, Kubelik AR, Livak KJ, Rafalski JA, et al. (1990). DNA polymorphisms amplified by arbitrary primers are useful as genetic markers. Nucleic Acids Res. 18: 6531-6535.

Yap IV and Nelson RJ (1996). Winboot: a Program for Performing Bootstrap Analysis of Binary Data to Determine the Confidence Limits of UPGMA-Based Dendrograms. IRRI, Manila.

Zolan ME and Pukkila PJ (1986). Inheritance of DNA methylation in Coprinus cinereus. Mol. Cell Biol. 6: 195-200. 